\title{
LtEPG1, a Secretory Endopolygalacturonase Protein, Regulates the Virulence of Lasiodiplodia theobromae in Vitis vinifera and Is Recognized as a Microbe-Associated Molecular Patterns
}

\author{
K. W. Thilini Chethana, ${ }^{1,2,3,4}$ Junbo Peng, ${ }^{1}$ Xinghong Li, ${ }^{1}$ Qikai Xing, ${ }^{1}$ Mei Liu, ${ }^{1}$ Wei Zhang, ${ }^{1}$ Kevin D. Hyde, $, 2,4$ \\ Wensheng Zhao, ${ }^{3}$ and Jiye Yan ${ }^{1, \dagger}$ \\ ${ }^{1}$ Beijing Key Laboratory of Environment Friendly Management on Fruit Diseases and Pests in North China, Institute of Plant and Environment \\ Protection, Beijing Academy of Agriculture and Forestry Sciences, Beijing 100097, China \\ ${ }^{2}$ Center of Excellence in Fungal Research, Mae Fah Luang University, Chiang Rai 57100, Thailand \\ ${ }^{3}$ College of Plant Protection, China Agricultural University, Beijing 100097, China \\ ${ }^{4}$ School of Science, Mae Fah Luang University, Chiang Rai 57100, Thailand \\ Accepted for publication 26 May 2020.
}

\begin{abstract}
The Lasiodiplodia theobromae genome encodes numerous glycoside hydrolases involved in organic matter degradation and conducive to pathogen infection, whereas their molecular mechanisms are still largely unknown. Here, we identified the glycoside hydrolase family 28 endopolygalacturonase LtEPG1 in $L$. theobromae and characterized its function in detail. LtEPG1 acts as a virulence factor during $L$. theobromae infection. Overexpression and silencing of $L t E P G 1$ in $L$. theobromae led to significantly increased and decreased lesion areas, respectively. Further, the high transcript level of $L t E P G 1$ during the infection process supported its virulence function. Polygalacturonase activity of LtEPG1 was substantiated by detecting its ability to degrade pectin. Furthermore, LtEPG1 functioned as microbe-associated molecular patterns during the infection process. Both transient expression of LtEPG1 in planta and infiltration of purified LtEPG1 triggered cell death in Nicotiana
\end{abstract}

ABSTRAC benthamiana. Site-directed mutation of LtEPG1 indicated that the enzymatic activity of LtEPG1 is independent from its elicitor activity. A protein kinase, KIN $\beta 1$, was shown to interact in the yeast two-hybrid system with LtEPG1. This interaction was further confirmed in vitro using a pull-down assay. Our data indicate that LtEPG1 functions as a polygalacturonase and also serves as an elicitor with two independent mechanisms. Moreover, LtEPG1 may be able to manipulate host immune responses by regulating the KIN $\beta 1$-mediated signal pathway and consequently promote its own successful infection and symptom development.

Keywords: cell death, elicitor activity, endopolygalacturonase activity, genetics and resistance, glycoside hydrolase family, Lasiodiplodia theobromae, mycology
The plant cell wall is the first layer encountered by fungal pathogens during their invasion into host plants. The basic structure of the plant cell wall is a complex of cellulose microfibrils embedded in a matrix consisting of hemicellulose, lignin, pectin, and structural proteins (Cosgrove 2005; Kubicek et al. 2014). Among these biopolymers, pectin, a heteropolysaccaride accounting for $35 \%$ of the primary cell wall, is a major constituent of the middle lamella of the primary cell wall of dicotyledonous plants (Kubicek et al. 2014; van der Vlugt-Bergmans et al. 2000; Voragen et al. 2009). Woody dicots, including many economically important plants, are significantly rich in pectin and its derivatives in their plant cell walls (Mellerowicz et al. 2001). Pectin not only is important for the integrity and rigidity of the plant cell wall and other plant tissues, but it also plays a vital role in the defense against wounding and plant pathogens (Mohnen 2008; Voragen et al. 2009).

†Corresponding author: J. Yan; jiyeyan@vip.163.com

Funding: This research was funded by National Natural Science Foundation of China (NSFC 31871919), China Agriculture Research Systems (CARS-29), and Beijing Academy Innovation Foundation (JKZX201905).

First and second authors contributed equally to this work.

*The $e$-Xtra logo stands for "electronic extra" and indicates there are supplementary materials published online.

The author(s) declare no conflict of interest.

(c) 2020 The American Phytopathological Society
Phytopathogenic fungi, especially those that do not possess specialized penetration structures, for example, Botryosphaeria dothidea, Coniella vitis, Diplodia corticola, Lasiodiplodia theobromae, and Phyllosticta ampelicida (Wilcox et al. 2015), produce diverse cell wall-degrading enzymes (CWDEs) to deconstruct the plant cell wall polymers, such as cellulose, pectin, and xylan. Furthermore, a considerable portion of CWDEs secreted by pathogens (Ma et al. 2015; Poinssot et al. 2003; Zhang et al. 2014) or even the decomposition products of cell walls have been identified as pathogen-associated molecular patterns during their interactions with host plants (Cheung et al. 2008; D'Ovidio et al. 2004; Hématy et al. 2009; Liu et al. 2015; Ma et al. 2015; Sakamoto et al. 2009; Yang et al. 2007). Based on sequence similarities, these CWDEs with pectin-degrading ability have been classified mainly into the glycoside hydrolase family 28 (GH28) (Henrissat 1991).

As an important member of CWDEs, endopolygalacturonases belong to the GH28 family and have been identified and characterized in various fungi (Herron et al. 2000; Kjøller and Struwe 2002; Reignault et al. 2007). For example, the importance of endopolygalacturonases functioning as virulence factors for fungal pathogenicity has been proven in Alternaria citri (Isshiki et al. 2001), Aspergillus flavus (Shieh et al. 1997), Botrytis cinerea (Kars et al. 2005; ten Have et al. 1998), Claviceps purpurea (Oeser et al. 2002), and Fusarium oxysporum (Durrands et al. 1988; Howell 1976; Mann 1962). In contrast, several studies have shown that endopolygalacturonases are not important for the infection process (Gao et al. 1996; Scott-Craig et al. 1990). These results indicate that endopolygalacturonases play multiple roles during the infection process. Although the functional mechanisms of endopolygalacturonases have been investigated in 
different organisms (Di Pietro and Roncero 1998; Isshiki et al. 2001; Kars et al. 2005; Poinssot et al. 2003; Shieh et al. 1997; ten Have et al. 1998), the molecular function of its ortholog in L. theobromae is still unclear.

L. theobromae, the causal agent of grape canker disease, has been described as a latent pathogen, and the lifestyle of $L$. theobromae can change from endophytic to pathogenic in the presence of external stimuli resulting from changing environmental conditions inside the host such as changes in host behavior or microbial equilibrium, or outside the hosts such as changes in climate or extreme environmental events (Chethana et al. 2016; Slippers and Wingfield 2007). Diseases caused by $L$. theobromae has been reported to bring a considerable yield loss to the grape industry, but the pathogenic mechanisms of this fungus are poorly characterized.

In our previous study, we identified 315 glycoside hydrolase family genes based on genome and transcriptome analyses in L. theobromae (Yan et al. 2018), among which 14 genes are GH28 family members, which is the highest number of $\mathrm{GH} 28$ family genes recorded for any fungi. In addition, 4 of 14 genes were up-regulated during infectious stages, suggesting that $L$. theobromae has an intense capacity for cell wall pectin degradation. Among these four genes, the transcript level of LtEPG1 (L. theobromae endopolygalacturonase 1) was up-regulated significantly during the infection process. In this study, it was found that LtEPG1 could be secreted into the extracellular space and function as a virulence factor. Furthermore, LtEPG1 was confirmed to be able to degrade pectin from citrus peel, and it could also trigger the cell death of Nicotiana benthamiana. Additionally, site-directed mutation of LtEPG1 showed that the elicitor activity of LtEPG1 was independent of its enzymatic activity. Together, these results indicate that LtEPG1 plays important roles in multiple aspects including pathogenesis, pectin degradation, and immune response regulation during the successful infection of $L$. theobromae.

\section{MATERIALS AND METHODS}

Fungal and bacterial isolates, culture conditions, and plant material. L. theobromae isolate CSS-01s was obtained from the Beijing Academy of Agricultural and Forestry Sciences, Beijing, China. Yeast strain YTK12 and Burkholderia glumae strain were obtained from Wenxian Sun at China Agricultural University. The $p E T-32 a$ vector used in this study were obtained from Zejian Guo at China Agricultural University. Cultures were grown on potato dextrose agar (PDA [1 liter]: $200 \mathrm{~g}$ of potato, $20 \mathrm{~g}$ of dextrose, and $20 \mathrm{~g}$ of agar) medium at $28^{\circ} \mathrm{C}$. All of the fungal cultures and bacterial cultures in the study were stored on PDA slants at $4^{\circ} \mathrm{C}$ and in $50 \%$ glycerol at $-80^{\circ} \mathrm{C}$, respectively. For RNA extraction, fungal mycelia were cultured in complete medium broth (CM: $0.6 \%$ [wt/vol] yeast extract, $0.3 \%$ [wt/vol] casein acid hydrolysate, $0.3 \%$ [wt/vol] casein enzymatic hydrolysate, and $1 \%$ [wt/vol] sucrose) in Erlenmeyer flasks on a shaking incubator at $160 \mathrm{rpm}$ and $25^{\circ} \mathrm{C}$ for 2 days. For plasmid extraction and protein expression, bacteria were cultured in Luria-Bertani (LB: 1\% [wt/ $\mathrm{vol}]$ tryptone, $0.5 \%$ [wt/vol] yeast extract, and $1 \%[\mathrm{wt} / \mathrm{vol}] \mathrm{NaCl}$ at $\mathrm{pH}$ 7.5) broth supplemented with their respective antibiotics at $37^{\circ} \mathrm{C}$ in a shaking incubator at $160 \mathrm{rpm}$. Green shoots of Vitis vinifera 'Summer Black' were obtained from Yanqing, China, and the $N$. benthamiana plants were grown and maintained at $25^{\circ} \mathrm{C}$ in the controlled growth chamber at Beijing Academy of Agriculture and Forestry Sciences, Beijing, China. Agar and peptone were purchased from Bacto (Becton, Dickinson and Company, MD, U.S.A.), and yeast extracts were purchased from Oxoid (Oxoid Ltd., U.K.). All chemicals and reagents used in specific experiments were purchased from Sigma-Aldrich Co. (U.S.A.). Restriction enzymes, LA Taq polymerases, and T4 ligase were supplied by TaKaRa Bio, Inc. (Japan). Escherichia coli strains DH5 $\alpha$ and BL21 and pMD18$T$ simple blunt vectors (TaKaRa Bio Inc.) were used for DNA manipulations and amplification.
Bioinformatic analysis. The GH28 domain of LtEPG1 was identified via pBlast against the Pfam database with the amino acid sequence of LtEPG1 as the query sequence and the default settings of the server. The signal peptide of LtEPG1 was predicted by the SignalP 4.1 server with the default settings (http://www.cbs.dtu.dk/ services/SignalP/). Putative GH28 family protein sequences of botryosphaeriaceous species and their homologs from other closely related species were downloaded. Downloaded sequences were aligned using the default settings of MAFFT version 7 (Katoh and Toh 2008) (https://mafft.cbrc.jp/alignment/server) and improved manually using BioEdit (Hall 1999). Maximum parsimony analyses were conducted for the GH28 family proteins in PAUP (phylogenetic analysis using parsimony) v.4.0b1037 (Swofford 2002) using the heuristic search option with tree bisection-reconnection branch swapping and 1,000 random sequence additions. Ambiguous regions in both alignments were excluded, and gaps were treated as missing data. Clade stabilities were assessed using a bootstrap analysis with 1,000 replications (Hillis and Bull 1993). Maxtrees were set to 1,000 , branches of zero length collapsed, and all multiple parsimonious trees were saved. Phylogenetic trees were graphically viewed using Treeview v.1.6.6 (Page 1996).

Functional validation of the predicted signal peptide using yeast secretion assay. Functional validation of the predicted signal peptide of LtEPG1 was performed within an invertase secretion-defective yeast ( $\mathrm{Gu}$ et al. 2011). During the experiment, the encoding sequence of the $L t E P G 1$ signal peptide, a 0.2 -kb fragment from the start codon of $L t E P G 1$, was subcloned into the plasmid $p S u c 2 t 7 M 13$ ori ( $p S U C 2$ ), and the primers were listed in Table 1 (Jacobs et al. 1997). The resultant fusion plasmids were transformed into the invertase secretion-defective yeast strain YTK12 by the lithium acetate method described in Becker and Lundblad (1994). Transformants were plated on YPDA medium (1\% yeast extract, $2 \%$ Difco peptone, $2 \%$ glucose, $0.003 \%$ adenine hemisulfate, and $2 \%$ agar), CMD-W medium $(0.67 \%$ yeast nitrogen base without amino acids, $0.075 \%$ tryptophan dropout supplement, $0.1 \%$ glucose, $2 \%$ sucrose, and $2 \%$ agar) (Treco and Lundblad 1993), and YPRAA medium (1\% yeast extract, $2 \%$ peptone, $2 \%$ raffinose, and antimycin A at $2 \mu \mathrm{g} \mathrm{ml}^{-1}$ ) (Jacobs et al. 1997). The parental strain YTK12 and the strain transformed with $p S U C 2$ were used as negative controls. Plates were photographed after 4 days of incubation at $28^{\circ} \mathrm{C}$.

Induction of cell death in $N$. benthamiana. The induction of cell death elicited by $B$. glumae on $N$. benthamiana leaves was performed (Sharma et al. 2013). The LtEPG1 gene without the signal peptide encoding sequence and the stop codon was amplified using the primers listed in Table 1 and was subcloned into the vector pEDV5 (Fabro et al. 2011). B. glumae competent cells were prepared by following the protocol given in Sharma et al. (2013). The confirmed constructs were transformed into the B. glumae competent cells by electroporation (Bio-Rad MicroPulser, Champaign, IL). Transformed strains were screened on LB agar supplemented with gentamycin at $25 \mathrm{mg} \mathrm{liter}^{-1}$. $N$. benthamiana plants were infiltrated with bacterial inocula of positive transformants (suspended in a $0.9 \% \mathrm{NaCl}$ ) at optical density $(\mathrm{OD})_{600}=$ 0.4 using a $1-\mathrm{ml}$ needleless syringe. The left half of the leaf was injected with $B$. glumae carrying the $p E D V$ empty vector, and the right half was injected with $B$. glumae carrying $p E D V: L t E P G 1$. The experiment was conducted independently three times, and each time, three leaves per plant and four plants were used as biological replicates. Plants were kept at $25^{\circ} \mathrm{C}$ in the controlled growth chamber at Beijing Academy of Agricultural and Forestry Sciences. Hypersensitive responses were observed within 3 days after infiltration.

Overexpression and RNAi vector construction of the LtEPG1 gene and the pathogenicity tests. The full-length coding sequence (without the stop codon) of $L t E P G 1$ was amplified with primers given in Table 1 and subcloned downstream of the PtrpC promoter in a modified $p$ Bluescript II $K S$ vector. The LtEPGI 
gene fused with the modified $K S$ vector was transformed into L. theobromae strain CSS-01s using the $\mathrm{PEG} / \mathrm{CaCl}_{2}$ transformation method (Yan et al. 2018). Transformants were screened using neomycin at 1,100 $\mathrm{g} \mathrm{ml}^{-1}$ (Sigma-Aldrich, U.S.A.), and positive transformants were confirmed via quantitative real-time PCR (qRTPCR). Then, the overexpression transformants of the $L t E P G l$ gene were subjected to pathogenicity tests on detached $V$. vinifera 'Summer Black' green shoots with methods described previously (Yan et al. 2018). The inoculated grape shoots were maintained on an alternating dark/light cycle at $25^{\circ} \mathrm{C}$ in the controlled growth chamber for three days. The experiment was conducted independently three times, and each time, 10 shoots were used as biological replicates for each overexpressed transformant of LtEPG1. Three days postinoculation, lesion length was recorded for each transformant, and one-way analysis of variance (ANOVA) was used to analyze data obtained from the pathogenicity tests at a 5\% significance level. The analysis was implemented in the MINITAB statistical program v.16.0 (Minitab Inc., U.S.A.). Shapiro-Wilk and Jarque-Bera normality tests were conducted for all datasets. The means of the different isolates were compared using Fisher's test at the $5 \%$ significance level.

For the RNAi vectors, the sense fragment and antisense fragment of LtEPG1 gene were amplified using primers given in Table 1. Then, the amplified fragments were ligated and expressed under the PtrpC promoter. The RNAi construct of LtEPG1 gene was transformed into $L$. theobromae strain CSS-01s with the method used for the overexpression transformation. Subsequent pathogenicity tests and data analyses were performed using the same methods adopted for the overexpression experiment.

RNA extraction and quantitative real-time reverse transcription PCR analyses. Total RNA was extracted from vegetative hyphae that were cultured in liquid complete media at $28^{\circ} \mathrm{C}$ in a shaking incubator at $160 \mathrm{rpm}$ for 2 days. Total RNA was isolated with Ambion Trizol Reagent (Life Technologies, U.S.A.) (Pham et al. 2011). The RNA concentration was quantified using a NanoDrop 2000c spectrophotometer (Thermo Scientific, U.S.A.). Then, the isolated RNA ( $3 \mu \mathrm{g})$ was reverse transcribed to cDNA for the subsequent qRT-PCR experiment.

qRT-PCR was conducted for the overexpression and RNAi transformants of LtEPGl using gene specific primers listed in
Table 1 in a 7500 real-time PCR system (Applied Biosystems, Singapore) with SYBR Premix Ex Taq II (Tli RNaseH Plus) (TaKaRa Bio Inc., China). The Actin gene of L. theobromae was used as the internal reference. qRT-PCR was performed in $15-\mu 1$ final volume consisting of $1.0 \mu \mathrm{l}$ of cDNA, $0.5 \mu \mathrm{l}$ of primer $(10 \mu \mathrm{M})$, $0.3 \mu \mathrm{l}$ of ROX reference dye, $5.2 \mu \mathrm{l}$ of sterile water, and $7.5 \mu \mathrm{l}$ of $2 \times$ SYBR Premix Ex Taq. The amplification conditions were as follows: $2 \mathrm{~min}$ for denaturation at $95^{\circ} \mathrm{C}$, followed by 40 cycles of $95^{\circ} \mathrm{C}$ for $5 \mathrm{~s}$, and $60^{\circ} \mathrm{C}$ for $35 \mathrm{~s}$. Relative gene expression was calculated using the $2^{-\Delta \Delta \mathrm{Ct}}$ method. The experiment was conducted thrice with three independent replicates for each of the selected transformants.

Expression and purification of LtEPG1 and point mutation form. The coding sequence of LtEPG1 was obtained and ligated into the expression vector $p E T-32 a$. The point mutation forms of LtEPG1 were obtained by following the PCR-mediated splicing overlap extension approach as described in Horton (1995). Subsequently, the fusion construct was transformed into E. coli strain BL21 as explained by Sugantha Priya et al. (2010). A positive clone was cultured in $200 \mathrm{ml}$ of $\mathrm{LB}$ broth at $37^{\circ} \mathrm{C}$. When the $\mathrm{OD}_{600}$ of the $E$. coli culture reached approximately 0.6 , an appropriate amount of isopropyl- $\beta$-D-thiogalactoside (IPTG) was added at a final concentration of $0.2 \mathrm{mM}$ to induce protein expression (Drew et al. 2001). Subsequently, the cultured bacteria were collected and sonicated on ice using the SONICS Vibra-cell Sonicator (Sonic \& Materials, CT, U.S.A.). Cells were sonicated at $50 \%$ duty cycle 60 times, consisting of $4 \mathrm{~s}$ bursts with $2 \mathrm{~s}$ intervals. Then, the sonication mixture was centrifuged for $30 \mathrm{~min}$ at $12,000 \mathrm{rpm}$ under $4^{\circ} \mathrm{C}$. LtEPG1 existed in the supernatant and was further purified with $\mathrm{Ni}$ NTA His bind resin (Qiagen, U.S.A.). A total of $5 \mathrm{ml}$ of protein solution was obtained and $5 \mu \mathrm{l}$ of protein was loaded into the sodium dodecyl sulfate-polyacrylamide gel electrophoresis (SDS-PAGE) gel. After running the gel, purified proteins were detected following Coomassie brilliant blue staining.

The purified proteins were adjusted to a final concentration of $700 \mathrm{nM}$ and then agroinfiltrated onto 4-week-old $N$. benthamiana leaves. Plants were kept at $25^{\circ} \mathrm{C}$ in the controlled growth chamber, and cell death responses were observed within 5 days after infiltration. Then, N. benthamiana leaves were stained with lactophenol/ethanol/trypan blue $(10 \mathrm{ml}$ of lactic acid, $10 \mathrm{ml}$ of

TABLE 1. Primers used in the current study

\begin{tabular}{|c|c|c|}
\hline Primer name & Sequence & Remarks \\
\hline \multicolumn{3}{|c|}{ Primers used in yeast complementary experiments } \\
\hline LtEPG1FE & 5'-ATGAATTCATGGTCAAGGTTTCCACCCT-3' & EcoRI site is underlined \\
\hline LtEPG1RX & 5'-TT $\overline{\mathrm{CTCGAG}}$ GATGGCAGAGGCAGC-3' & $\mathrm{XhoI}$ site is underlined \\
\hline LtEPG1FSal & 5'-TAGTCGACGCCCCCACTGAGCTC-3' & SalI site is underlined \\
\hline LtEPG1RBam & 5'-AAGGATCC $\overline{G C A A G A G A T G C C A G A G C-3 ' ~}$ & BamHI site is underlined \\
\hline \multicolumn{3}{|c|}{ Primers used for the overexpression vector construction } \\
\hline LtEPG1FEco & 5'-TCAAGCTTATGGTCAAGGTTTCCA-3' & EcoRI site is underlined \\
\hline RiLtEPG1SFPst & 5'-AACTGCAGAAGGTTTCCACCCTCCTT-3' & PstI site is underlined \\
\hline RiLtEPg1SRSal & 5'-ATGTCGACGACTTCAGGCCAGTGAGA-3' & SalI site is underlined \\
\hline \multicolumn{3}{|c|}{ Primers used for the RNAi vector construction: Antisense strand } \\
\hline RiSLtEPG1ASEF & 5'-AAGAATCCAAGGTTTCCACCCTCCTT-3' & EcoRI site is underlined \\
\hline RiSLtEPG1ASXhF & 5'-ATCTCGAGGACTTCAGGCCAGTGAGA-3' & $\mathrm{XhoI}$ site is underlined \\
\hline \multicolumn{3}{|c|}{ Primers used for the transcript level analyses of $L t E P G 1$ gene in overexpression and RNAi transformants of $L t E P G 1$} \\
\hline QLtEPG1F & 5'-TTCGGTTACAAGGAGTGGGAG-3' & - \\
\hline \multicolumn{3}{|c|}{ Primers used for the construction of LtEPG1-pGBKT7 fusion construction } \\
\hline LtEPG1BDF & 5'-CGGAATTCATGGTCAAGGTTTCCACCC-3' & EcoRI site is underlined \\
\hline LtEPG1BDR & 5'-CG $\overline{\text { GGATCC}}$ TTAGCAAGAGATGCCAGAG-3' & BamHI site is underlined \\
\hline \multicolumn{3}{|c|}{ Primers used for the confirmation of positive transformants screened by yeast two-hybrid } \\
\hline Y2HPF & 5'-GCACCTATTCGATGATGAAGATACC-3' & - \\
\hline Y2HPR & 5'-GCACGATGCACAGTTGAAGTG-3' & - \\
\hline
\end{tabular}


glycerol, $10 \mathrm{~g}$ of phenol, $30 \mathrm{ml}$ of absolute ethanol, and $10 \mathrm{mg}$ of trypan blue dissolved in $10 \mathrm{ml}$ of distilled water) via boiling in lactophenol/ethanol/trypan blue solution for $5 \mathrm{~min}$, followed by destaining in chloral hydrate at $2.5 \mathrm{~g} \mathrm{ml}^{-1}$.

Polygalacturonase activity assay. According to Miller (1959), polygalacturonase activity was determined by measuring the product absorbency at $575 \mathrm{~nm}$ caused by the release of reducing sugars from citrus pectin. Three separate reactions were conducted for a series of different enzyme volumes $(0.2,0.4,1,5$, and $10 \mu \mathrm{l})$, with each volume represented by three replicates. The concentration of the enzyme was measured by flowing the Bradford assay (Bio-Rad Protein Assay) according to the manufacturer's instructions. The reaction mixtures consisted of (i) $250 \mu \mathrm{l}$ of citrus pectin at $2 \mathrm{mg} \mathrm{ml}^{-1}$ (Sigma-Aldrich, China) dissolved in $0.1 \mathrm{M}$ sodium acetate buffer ( $\mathrm{pH} 5.0)$ and the enzyme $\left(0.1 \mathrm{mg} \mathrm{ml}^{-1}\right)$, (ii) $250 \mu \mathrm{lof}$ glucose at $2 \mathrm{mg} \mathrm{ml}^{-1}$ and the enzyme $\left(0.1 \mathrm{mg} \mathrm{ml}^{-1}\right)$, and (iii) $125 \mu \mathrm{l}$ of citrus pectin at $2 \mathrm{mg} \mathrm{ml}^{-1}$ dissolved in $0.1 \mathrm{M}$ sodium acetate buffer (pH 5.0), $125 \mu \mathrm{l}$ of glucose at $2 \mathrm{mg} \mathrm{ml}^{-1}$, and the enzyme $\left(0.1 \mathrm{mg} \mathrm{ml}^{-1}\right)$. The mixture was incubated at $45^{\circ} \mathrm{C}$ for $30 \mathrm{~min}$, and the reaction was stopped with the addition of $750 \mu \mathrm{l}$ of di-nitro salicylic acid reagent, boiled for $5 \mathrm{~min}$, and cooled on ice. Then, the absorbance of each mixture was measured in an Ultrospec 2100 pro UV/Visible Spectrophotometer (Amersham Biosciences, Sweden) at $575 \mathrm{~nm}$.

\section{A LtEPG1}

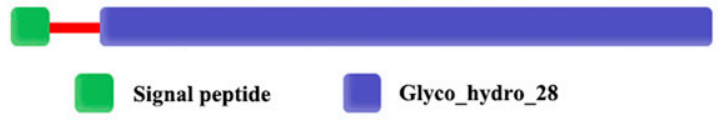

B

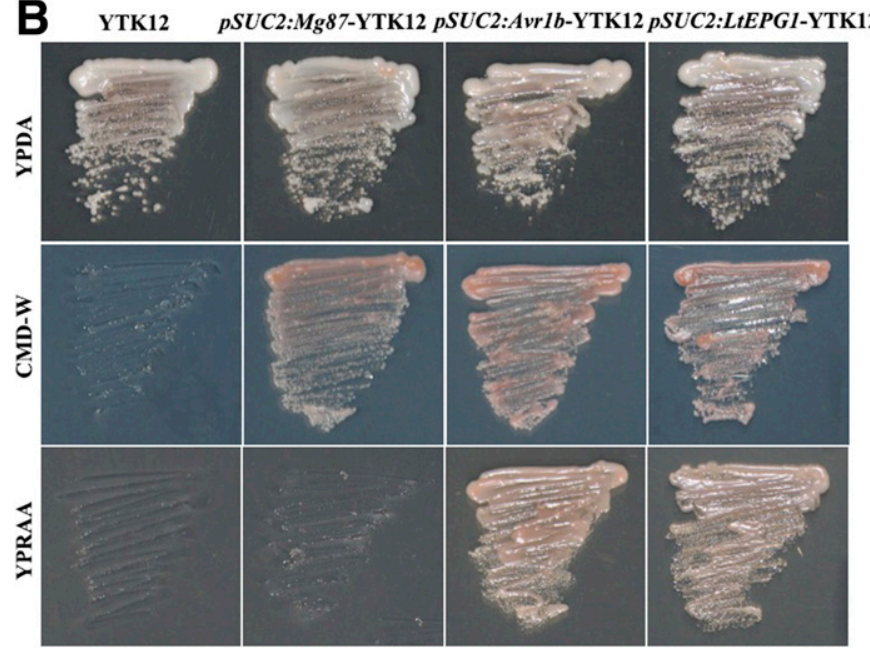

Fig. 1. Functional validation of the predicted signal peptide of the LtEPG1 (Lasiodiplodia theobromae endopolygalacturonase 1) protein. A, Schematic diagram of LtEPG1. B, Functional detection of the signal peptide of the LtEPG1. The encoding sequence of the predicted signal peptide of LtEPG1 was fused upstream of the truncated form of the yeast invertase gene that lacked its own native signal peptide sequence to engineer the fusion construct pSUC2:LtEPG1. Yeast strain YTK12 transformed with the pSUC2:LtEPG1 fusion vector was cultured on YPDA (1\% yeast extract, $2 \%$ Difco peptone, $2 \%$ glucose, $0.003 \%$ adenine hemisulfate, and $2 \%$ agar), CMD-W $(0.67 \%$ yeast nitrogen base without amino acids, $0.075 \%$ tryptophan dropout supplement, $0.1 \%$ glucose, $2 \%$ sucrose, and $2 \%$ agar), and YPRAA (1\% yeast extract, $2 \%$ peptone, $2 \%$ raffinose, and antimycin $\mathrm{A}$ at $2 \mu \mathrm{g} \mathrm{ml}^{-1}$ ) media and photographed after 4 days of incubation. All yeast strains grew on YPDA. Transformants carrying the $p S U C 2$ fusion plasmid grew on CMD-W. Only transformants whose invertase could be secreted into the extracellular space grew on YPRAA plates. YTK12 denotes the parental strain. $p S U C 2: A v r 1 b$-YTK12 was used as the positive control, and $p S U C 2: M g 87-Y T K 12$ was used as a negative control. pSUC2:LtEPG1-YTK12 denotes LtEPG1 transformants.
Yeast two-hybrid assay. The ORF of the LtEPG1 gene was cloned into the $p G B K T 7$ vector using the primers shown in Table 1 to construct the bait vector $p G B K T 7-L t E P G 1$. The bait plasmid was transformed into yeast strain AH109 by the lithium acetate method as described in Becker and Lundblad (1994). The grape cDNA library screening was performed with $p G B K T 7-L t E P G 1$ as the bait by following the Matchmaker Gold Yeast Two-Hybrid System (Clontech, TaKaRa, China). The fished transformants were selected on synthetic dropout (SD/-Leu/-Trp/-His) medium, and the interaction between the bait protein and prey target was further confirmed by yeast two-hybridization. Primers are listed in Table 1.

MBP pull-down assays. The LtEPG1 and KIN $\beta 1$ were cloned into $p G E X-4 T-1$ and pMAl-C4X vectors and expressed in E.coli BL21 to produce recombinant proteins. Protein purification and MBP pull-down assays were performed with the method described in a previous study (Liu et al. 2011).

\section{RESULTS}

LtEPG1 belongs to the GH28 family and is widely distributed across pathogenic fungal taxa. Based on genome and transcriptome analyses, it was found that four genes belonging to the $\mathrm{GH} 28$ family were up-regulated during the infection process. One of them, with a significantly elevated transcription level, was identified and referred to as LtEPGl (Yan et al. 2018). The 20 amino acids located at the N-terminal of LtEPG1 were predicted to be the signal peptide of LtEPG1 with SignalP 4.1 Server (Fig. 1A) (Petersen et al. 2011). Searching against the Pfam database with LtEPG1 as the query showed that LtEPG1 contains a Glyco_hydro_ 28 domain (PF00295) (Fig. 1A). Furthermore, conserved regions among the LtEPG1 protein and its closely related endopolygalacturonases were identified by amino acid sequence alignment (Supplementary Fig. S1). In the phylogenetic analysis, LtEPG1 was found to be clustered together with the other $\mathrm{GH} 28$ family proteins (Yan et al. 2018). The phylogenetic relationship between LtEPG1 and its homologs confirmed that LtEPG1 belongs to the same clade as another two putative endopolygalacturonases from botryosphaeriaceous pathogens Diplodia seriata and D. corticola (Supplementary Fig. S2).

After LtEPG1 was cloned, we used the amino acid sequence of LtEPG1 as a query in a blastp search against the L. theobromae proteome for other orthologs. Interestingly, three more proteins with the accession numbers KAB2578544.1, KAB2575894.1, and KAF4546527.1 were identified to share 82.38 , 77.78, and $77.51 \%$ amino acid identities with LtEPG1, with 94, 100, and $100 \%$ coverages, respectively, and all of these proteins predicted to be polygalacturonases (Supplementary Fig. S3).

LtEPG1 encodes a secretory endopolygalacturonase protein. To validate the predicted exocrine ability of LtEPG1, an effective and efficient method of a trapping signal sequence was adopted, which has been widely used to identify the signal peptide of secretory proteins (Gu et al. 2011; Jacobs et al. 1997). To identify the signal sequence of $L t E P G 1$, we engineered an LtEPGISPinvertase fusion construct, in which the signal peptide of LtEPG1 was introduced one amino acid before the truncated moiety of yeast invertase whose signal peptide had been cleaved. A constructed fusion vector ( $p S U C 2: L t E P G 1)$ with positive $(p S U C 2: A v r 1 b)$ and negative controls ( $p S U C 2: M g 87$ ) was transformed into the $S U C 2^{-}$ yeast strain YTK12. As shown in Figure 1B, all of the yeast strains grew on YPDA medium, and yeast transformants carrying the $p S U C 2$ vector grew on CMD-W medium. However, only transformants $p S U C 2$ : LtEPG1-YTK12 carrying the LtEPG1 signal peptide and positive control containing pSUC2:Avrlb were able to rescue the growth of parental strain YTK12 on YPRAA plates, indicating that LtEPG1 has a functional signal peptide that can lead to the secretion of yeast invertase.

LtEPG1 is required for the full virulence of L. theobromae in $\boldsymbol{V}$. vinifera. Based on our previous transcriptome analysis (Yan et al. 2018), the transcript level of LtEPG1 
during the infectious stage was significantly higher $(\sim 4 \times)$ than that of vegetative mycelia. To determine the predicted contribution of LtEPG1 to L. theobromae virulence, expression patterns of LtEPG1 were analyzed during different infection stages, including the mycelia cultured in liquid CM medium, and 12, 24, 48 , and $72 \mathrm{~h}$ postinoculation on wounded grape shoots. Results combined with the statistical analysis showed that the expression of LtEPG1 was significantly increased during early infection stages (Fig. 2).

To functionally characterize LtEPG1, the LtEPG1 gene was overexpressed and silenced via PEG-mediated transformation in L. theobromae (Fig. 3A and B). The positive transformants were screened on neomycin-containing plates and confirmed by qRTPCR analysis (Fig. 3E). Phenotypic analyses show that $L t E P G l$ had no significant effect on colony morphology and vegetative growth on PDA (Fig. 3C and D).

Further virulence analysis was also performed by inoculating equal-diameter mycelial plugs from wild-type, overexpression transformants, and RNAi transformants onto green shoots of $V$. vinifera 'Summer Black', which is susceptible to L. theobromae. The overexpression transformants of LtEPG1 showed evidently elevated pathogenicity relative to that in the wild type, and the RNAi transformant of LtEPGl exhibited significantly decreased pathogenicity in comparison with that in the wild type. After $72 \mathrm{~h}$ postinoculation (hpi), the overexpression transformants displayed longer lesions with an average length of $5.12 \mathrm{~cm}$, and the RNAi transformants, by contrast, showed smaller lesions with an average length of $1.53 \mathrm{~cm}$, compared with the wild type, which has the average length of $3.56 \mathrm{~cm}$ (Fig. 3F and G). Taken together, these results indicate that LtEPG1 is important for the virulence and symptom development of $L$. theobromae.

LtEPG1 is an endopolygalacturonase. LtEPG1 has been predicted to be an endopolygalacturonase based on blastp analysis against the NCBI database, so we decided to investigate its enzymatic activity. Therefore, recombinant LtEPG1 was isolated from E. coli BL21 that carried the pET-32a:LtEPG1 fusion construct and was further purified with Ni-NTA beads. Purified proteins were detected by SDS-PAGE and visualized with Coomassie staining (Fig. 4A). Next, purified LtEPG1 protein was assayed for endopolygalacturonase activity using glucose and citrus pectin as substrates. According to the assay, the absorbance of reaction product derived from purified LtEPG1 and citrus pectin gradually increased at $575 \mathrm{~nm}$ when the volumes of purified LtEPG1 added to the citrus pectin were gradually increased (Fig. 4B). However, no obvious difference in absorbance was detected with increasing enzyme volumes when glucose was used as the substrate. Due to the strong reaction between glucose and di-nitro salicylic acid, a higher absorbance was detected at $575 \mathrm{~nm}$ compared with that of citrus pectin. Similarly, in the presence of both substrates, no significant changes were observed in absorbance at $575 \mathrm{~nm}$. The latter two results were expected since glucose has been shown to be able to repress polygalacturonase activity (Li et al. 2004). Since the absorbance values of the latter two reactions were beyond the measurable range, products of the latter two reactions were diluted before measuring the absorbance. These results indicate that LtEPG1 functions as an endopolygalacturonase with citrus pectin as the substrate.

LtEPG1 from $L$. theobromae can induce cell death in $N$. benthamiana. To assess whether LtEPG1 could elicit cell death response, transient expression of LtEPG1 in $N$. benthamiana was tested. We engineered the fusion vector $p E D V: L t E P G 1$ and transformed it into B. glumae competent cells, which has been reported to be able to induce cell death when transiently expressed in $N$. benthamiana (Sharma et al. 2013). Transformed bacteria carrying $p E D V: L t E P G 1-\mathrm{Bg}, p E D V-\mathrm{Bg}$, and empty $p E D V$ were agroinfiltrated into $N$. benthamiana leaves, respectively. Results showed that $p E D V: L t E P G 1-\mathrm{Bg}$ triggered a stronger cell death response 3 days postinfiltration compared with $p E D V-\mathrm{Bg}$, and empty $p E D V$ barely induce cell death (Fig. 5A).
To further confirm LtEPG1 could trigger a hypersensitive response in $N$. benthamiana, recombinant LtEPG1 was purified and then infiltrated into $N$. benthamiana leaves for cell death detection. Buffer was infiltrated as a control. As indicated in Figure 5C, LtEPG1-induced cell death in $N$. benthamiana leaves could be observed 5 days post protein infiltration. The results indicated that the prokaryotically expressed LtEPG1 could trigger significantly visible cell death similar to the transient expression of $L t E P G 1$ in planta.

Enzymatic activity of LtEPG1 is not required for its elicitor activity. As purified LtEPG1 has been confirmed to be an endopolygalacturonase and can also elicit the cell death response in $N$. benthamiana, further investigation was carried out to test whether the enzymatic activity of LtEPG1 is necessary for its elicitor activity. Amino acid sequence alignment of available polygalacturonases from plants, fungi, and bacteria showed that a total of eight amino acid residues of LtEPG1 are strictly conserved among these polygalacturonase orthologs. These eight residues are $\mathrm{Asn}^{182}, \mathrm{Asp}^{184}, \mathrm{Asp}^{205}, \mathrm{Asp}^{206}$, His ${ }^{227}, \mathrm{Gly}^{228}, \mathrm{Arg}^{260}$, and Lys ${ }^{262}$. To assess their importance for enzymatic activity and elicitor activity, six out of eight conserved residues-Asp ${ }^{184}, \mathrm{Asp}^{205}$, $\mathrm{Asp}^{206}$, His ${ }^{227}$, $\operatorname{Arg}^{260}$, and Lys ${ }^{262}$ - were mutagenized to Glu, Glu, Glu, Ala, Asn, and Asn, respectively (Supplementary Fig. S4). The mutated forms (D184E, D205E, D206E, H227A, R260N, and K262N) were expressed in E. coli and detected in SDS-PAGE (Fig. $5 \mathrm{~B})$. No differences were observed in the molecular weight between LtEPG1 and its mutated LtEPG1 forms (Fig. 5B). Polygalacturonase assays showed that the reaction products of pectin with mutated forms of LtEPG1 were hardly detected by di-nitro salicylic acid reagent, suggesting the enzymatic activity of mutated proteins was almost abolished or insignificant. These results indicate that these conserved residues are necessary for the enzymatic activity of LtEPG1.

To examine whether these conserved residues also affect the elicitor activity of LtEPG1, purified mutation forms of the LtEPG1 protein were infiltrated into the leaves of $N$. benthamiana. Total mutated proteins induced visible cell death in N. benthamiana (Fig. 5C) and the cell death lesion was detectable by trypan blue staining (Fig. 5D). Taken together, these results indicate that the elicitor activity of LtEPG1 is independent of its enzymatic activity.

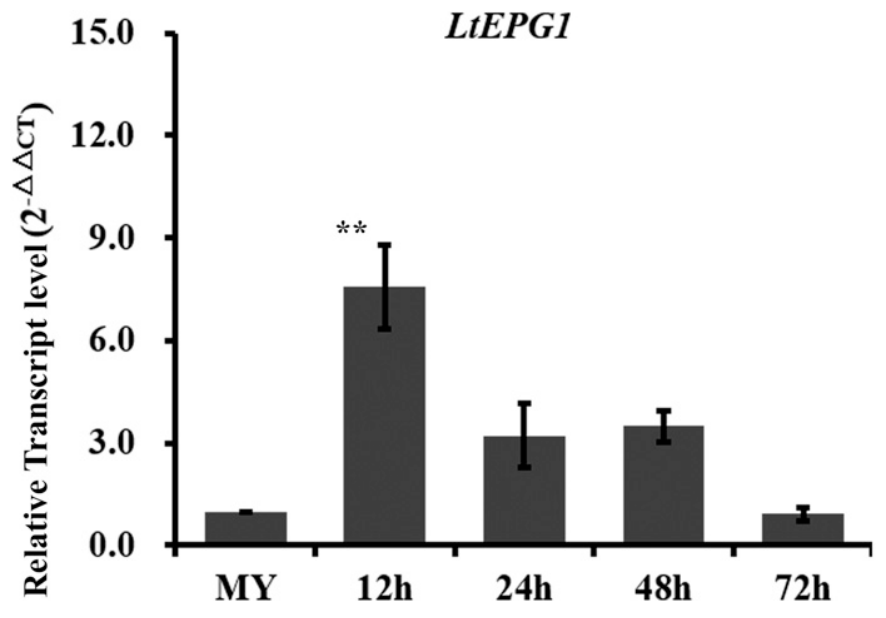

Fig. 2. Transcript levels of LtEPG1 at mycelial and different infection stages. Transcript levels of glycoside hydrolase family 28 endopolygalacturonase gene were assessed at the mycelial stage (MY), 12, 24, 48, and $72 \mathrm{~h}$ postinoculation in Vitis vinifera shoots using quantitative real-time PCR. Expression data were normalized by actin gene and calibrated against transcript level of the mycelial stage. Means and standard deviations from three biological replicates are shown. Asterisks (**) indicate significant differences as measured by least significant difference test $(P<0.01)$. 
A
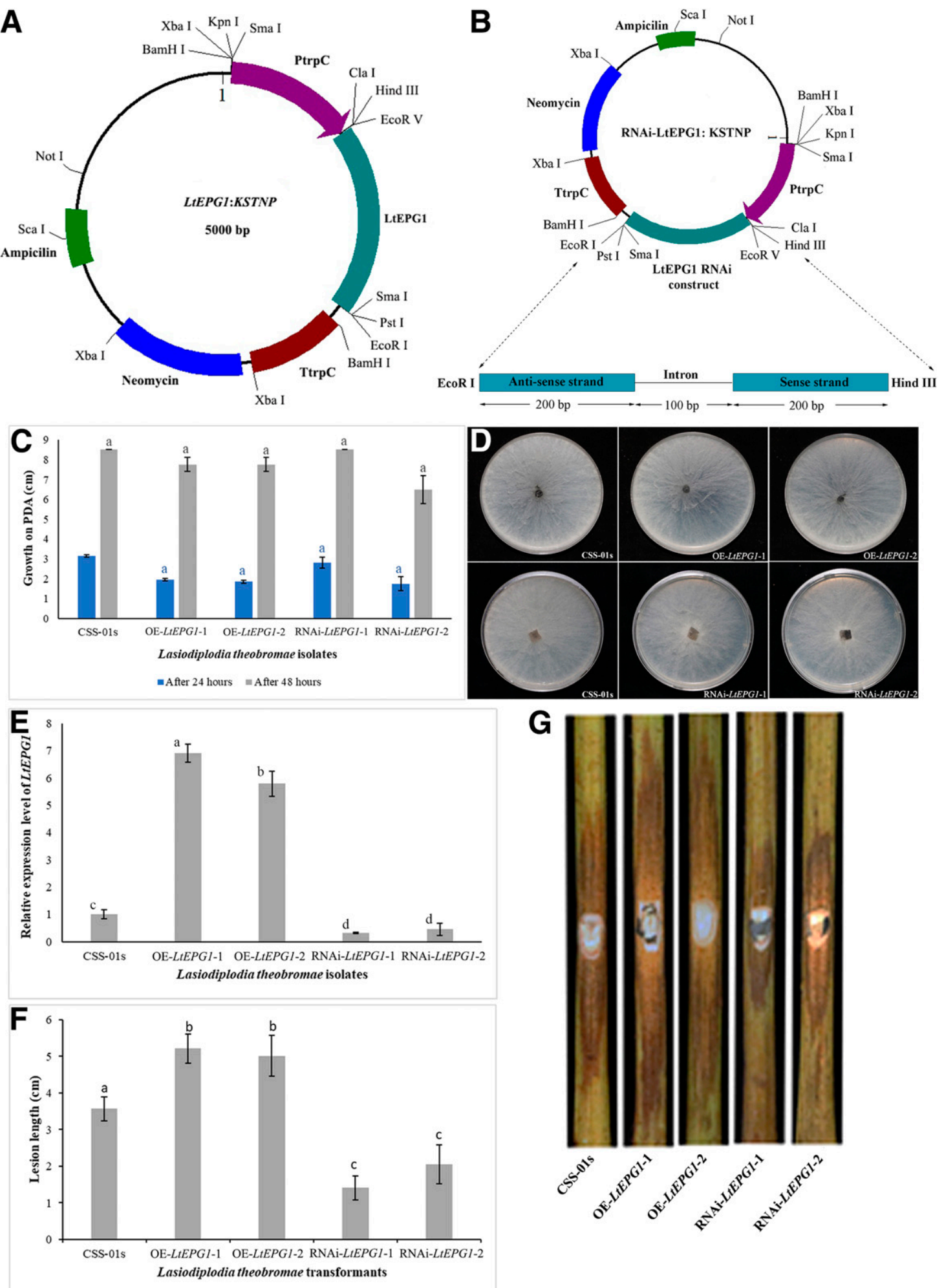

G

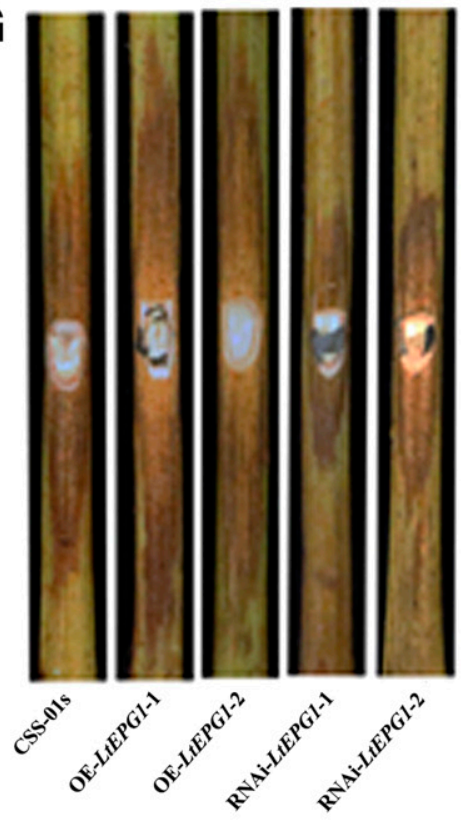

Fig. 3. LtEPG1 contributes to the virulence of Lasiodiplodia theobromae in Vitis vinifera shoots. A, Schematic diagram of the $L t E P G 1$ gene overexpression vector. $\mathbf{B}$, Schematic diagram of the LtEPG1 gene silencing vector. C, Radial growth rates of wild-type CSS-01s, overexpression transformants, and silencing transformants of $L t E P G 1$ after 24 and $48 \mathrm{~h}$ at $28^{\circ} \mathrm{C}$. Bars indicate the standard deviations of three biological replicates. One-way analysis of variance (ANOVA) was performed for statistical analysis. Isolates that do not share same letter exhibit significantly different growth rates among the isolates. D, Phenotypes of wild-type CSS-01s, overexpression transformants, and silencing transformants of $L t E P G 1$ after $48 \mathrm{~h}$ at $28^{\circ} \mathrm{C}$. E, The transcript level of $L t E P G 1$ in wild-type CSS-01s, overexpression transformants, and silencing transformants. Actin was used as the endogenous control. Means and standard deviations of three biological replicates are shown. One-way ANOVA was performed for statistical analysis. Isolates that do not share same letter exhibit significantly different gene expression among the isolates. F, Lesion lengths of the wild-type CSS-01s, overexpression transformants, and silencing transformants of LtEPG1. Bars indicate the standard deviations of 10 biological replicates. One-way ANOVA was performed for statistical analysis. Isolates that do not share same letter exhibit significantly different lesion lengths. G, Pathogenicity assay of wild-type, overexpression transformants, and silencing transformants of LtEPG1 in V. vinifera green shoots. OE-LtEPG1-1 and OE$L t E P G 1-2$ denote the $L t E P G 1$ overexpression transformants, and RNAi-LtEPG1-1 and RNAi-LtEPG1-2 denote the LtEPG1 silencing transformants. 
LtEPG1 interacts with KIN $\beta 1$. As LtEPG1 was confirmed to be a secretory protein, we conducted a yeast two-hybrid screen against the grape cDNA library with LtEPG1 as the bait to fish the potentially interacting targets of LtEPG1. As shown in Supplementary Figure S5, LtEPG1 did not display the transcriptional activation activity when the bait vector was expressed in yeast. Further, 16 proteins potentially interacting with LtEPG1 were identified as shown in supporting information in Supplementary Table S1. Among the 16 potential candidates, one protein named $\mathrm{KIN} \beta 1$, was selected for further analysis (Fig. 6A).

To confirm the interaction of LtEPG1 and KIN $\beta 1$, we expressed their full-length cDNA sequences in yeast. Results indicated that LtEPG1 indeed interacted with KIN $\beta 1$. We further confirmed interaction between LtEPG1 and KIN $\beta 1$ with MBP pull-down assays. Pull-down assays using the recombinant GST-LtEPG1 and MBP-KIN $\beta 1$ showed that two proteins interacted with each other in vitro (Fig. 6B).

The homolog of KIN $\beta 1$ was reported to be a regulatory subunit of the SNF1-related protein kinase complex (Tabata et al. 2000), but the functional analyses related to immune response in grape is barely reported. Here, the transcript level of $K I N \beta 1$ at different infection points was determined by qRT-PCR analysis (Supplementary Fig. S6). Surprisingly, the transcription level of $K I N \beta 1$ was significantly decreased during the early infectious stages, suggesting that KIN $\beta 1$ may function as an immune response regulatory factor, but its functional mechanisms need to be investigated in depth.

In summary, we assume a working model of LtEPG1 during the infection processes. LtEPG1 disrupts the plant cell wall components to facilitate the infection of $L$. theobromae; LtEPG1 interacts with KIN $\beta 1$, but the regulatory mechanisms of the interaction on the downstream signal pathways including burst of reactive oxygen species, increased expression of defense-related genes, and immune response need to be further investigated.

\section{DISCUSSION}

During plant-pathogen interactions, the plant cell wall represents a major barrier for the successful invasion of pathogens, and conversely, pathogens possess a diversified arsenal known as CWDEs to overcome these obstacles. Until now, a plethora of CWDEs have been reported to be conducive to the depolymerization of plant cell wall components, including cellulose, hemicellulose, lignin, pectin, xylan, and xyloglucan (Kubicek et al. 2014). Advances in genomic, transcriptomic and proteomic research have revealed large amounts of CWDE families that are
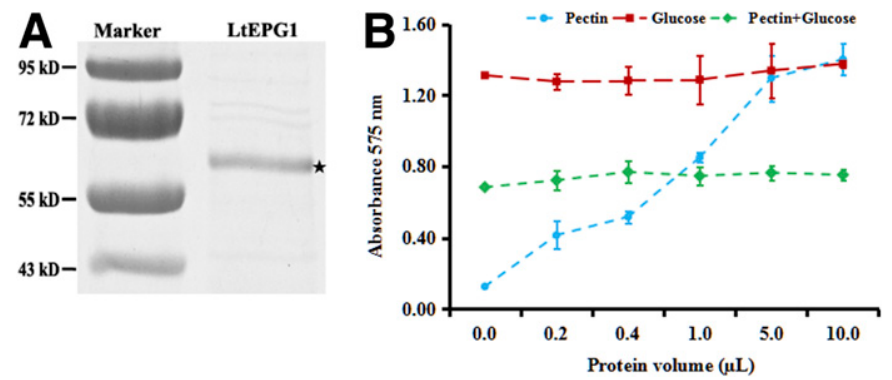

Fig. 4. The endopolygalacturonase activity analysis of LtEPG1. A, Sodium dodecyl sulfate-polyacrylamide gel electrophoresis was performed to confirm the expression of LtEPG1 in Escherichia coli. The gel was stained with Coomassie brilliant blue and scanned. Asterisk denotes the target protein. B, Results of endopolygalacturonase activity. Enzyme activity is reported as the increase in absorbance at $\mathrm{A}_{575 \mathrm{~nm}}$ from the release of reducing sugars from pectin. Bars indicate the standard deviation of three replicates. specifically present or magnified in different pathogenic fungi. Previous studies also showed that CWDEs were significantly essential, not only for the pathogens that lack specialized infection structures but also for many phytopathogenic fungi that depend on mono- and oligosaccharides liberated from plant tissues for their growth and reproduction (Gibson et al. 2011; Kubicek et al. 2014). Recent research (Yan et al. 2018) confirmed that L. theobromae possess a large number of CWDE-encoding genes, but the functional mechanisms of these CWDEs are still unknown.
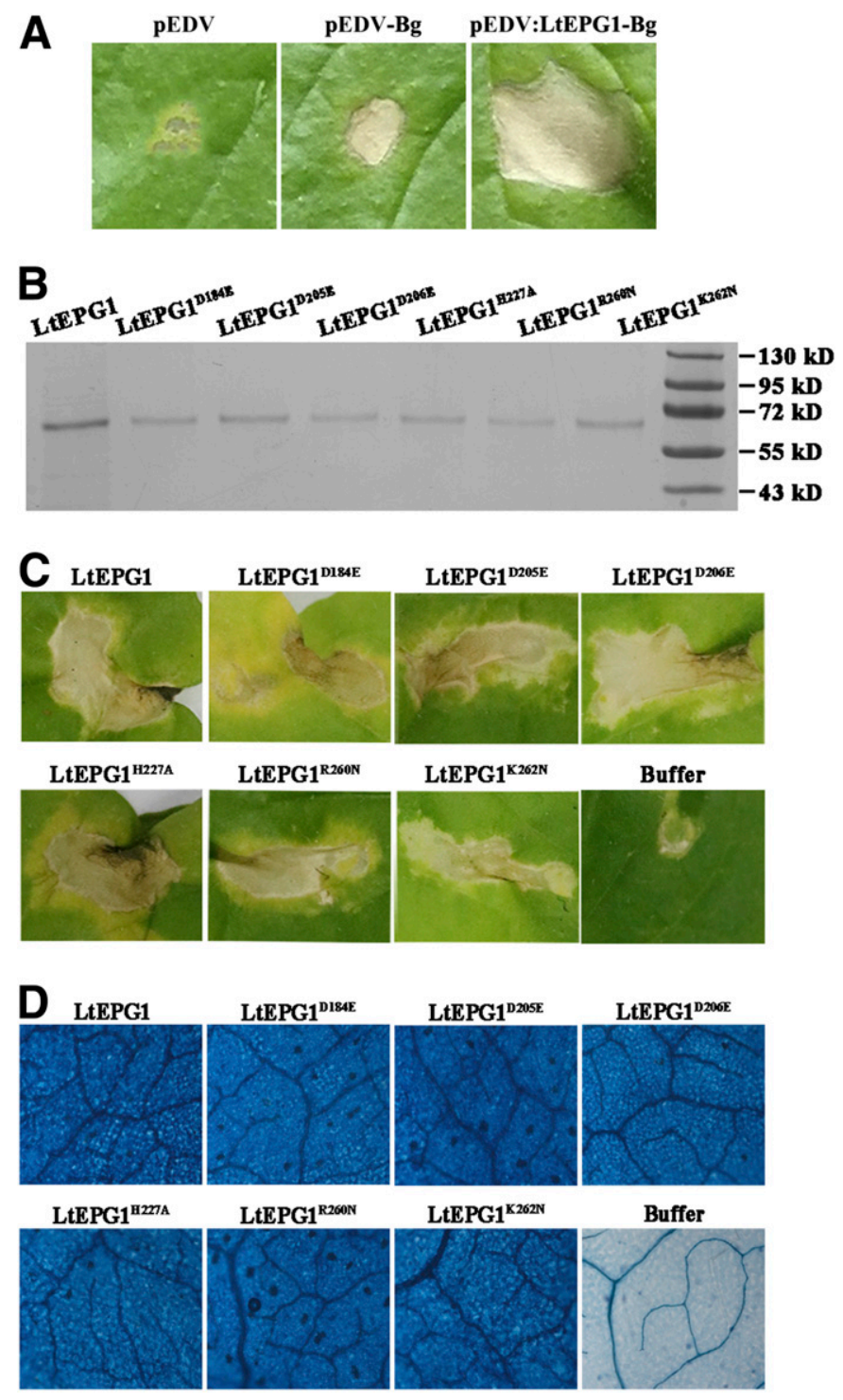

Fig. 5. LtEPG1 expression induces defense responses in Nicotiana benthamiana leaves. A, Transient expression of LtEPG1 elicits increased cell death responses in $N$. benthamiana leaves after infiltration with Burkholderia glumae harboring $p E D V-\mathrm{Bg}$ and $p E D V: L t E P G 1-\mathrm{Bg}$. Opposite areas of the leaf surface were infiltrated with $p E D V-\mathrm{Bg}$ and $p E D V: L t E P G 1-\mathrm{Bg}$. Representative cell death symptoms were photographed 3 days postinoculation. B, Sodium dodecyl sulfate-polyacrylamide gel electrophoresis analysis to confirm the expression of the protein LtEPG1 and its mutated forms in Escherichia coli. No differences in molecular weight were observed between LtEPG1 and its mutated LtEPG1 forms. WT denotes the LtEPG1 protein and D184E, D205E, D206E, H227A, R260N, and K262N denote the mutated forms of the LtEPG1 protein. C, Cell death in $N$. benthamiana leaves was assessed by visual inspection 5 days postinfiltration with purified LtEPG1 proteins and their mutated forms. LtEPG1 ${ }^{\text {D184E, LtEPG1 }}{ }^{\text {D205E }}$ LtEPG1 ${ }^{\text {D206E }}$ LtEPG1 $1^{\text {H227A }}$, LtEPG $1^{\mathrm{R} 260 \mathrm{~N}}$, and LtEPG1 ${ }^{\mathrm{K} 262 \mathrm{~N}}$ denote the mutated forms of the LtEPG1 protein. All of the mutated forms induced visible cell death in $N$. benthamiana leaves. D, Cell viability measured by trypan blue staining. 
Here, we identified a CWDE LtEPG1 in L. theobromae, which belongs to $\mathrm{GH} 28$ based on amino acid sequence alignment. Yeast complementary experiments showed the signal peptide of LtEPG1 was able to guide the secretion of yeast invertase, which indicated that LtEPG1 was secreted into extracellular spaces during the pathogen-plant interaction process. Amino acid sequence analyses showed that LtEPG1 has a GH28 domain, suggesting that LtEPG1 can function as an endopolygalacturonase. Enzymatic activity evaluation confirmed that LtEPG1 has enzymatic activities with pectin as its substrate, and the hydrolytic reaction can be repressed by glucose, which is consistent with previously reported results (Di Pietro and Roncero 1998; Kubicek et al. 2014). The hydrolysis ability of LtEPG1 suggests that $L$. theobromae may be able to decompose the cell wall component of host plants during the infection process to support disease development.

Moreover, many polygalacturonases have been reported as virulence factors in plant pathogens, such as $\operatorname{Pg} 1$ in the wilt pathogen F. oxysporum (Di Pietro and Roncero 1998), Acpg1 in the citrus pathogen Alternaria citri (Isshiki et al. 2001), and Bcpg1 to Bcpg6 in the grapevine pathogen B. cinerea (Kars et al. 2005; Poinssot et al. 2003; ten Have et al. 1998). Similar to previous studies, LtEPG1 was also confirmed to be a virulence factor by overexpression and RNAi in combination with pathogenicity tests. LtEPG1, however, had no influence on the phenotypes, including fungal morphology and colony characteristics, suggesting that LtEPG1 may mainly function during the infection process. Furthermore, the involvement of LtEPG1 in the infection process was further confirmed by qRT-PCR. The increased transcript level of LtEPG1 at $12 \mathrm{hpi}$ indicates that LtEPG1 has more active roles during the early infection stages, most probably activating its putative polygalacturonase activity with plant cell wall components as its substrate. Symptoms became visible at $24 \mathrm{hpi}$ on the green shoots. This timing lacks behind $L t E P G 1$ gene expression probably because several mechanisms need to work together after gene expression for physical damage to appear. Moreover, eight conserved amino acids were also identified in LtEPG1 according to amino acid sequence alignment against its orthologs. Surprisingly, single site-substitution of these amino acid residues led to almost complete loss of enzymatic activity, which concurs with the documented results in other fungi (van Santen et al. 1999).

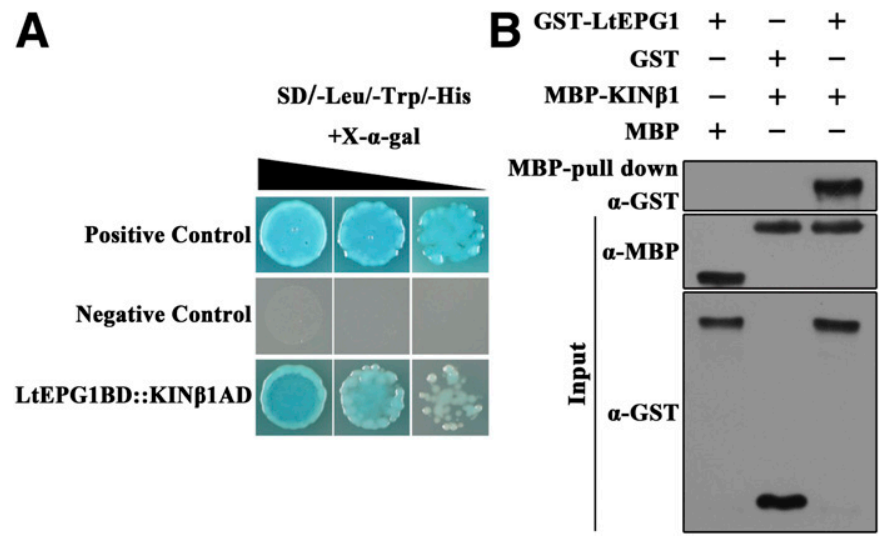

Fig. 6. LtEPG1 interacts with the Vitis vinifera KIN $\beta 1$ protein. A, LtEPG1 interacts with KIN $\beta 1$ confirmed by yeast two-hybrid assay. Yeast cells expressing the prey construct of KIN $\beta 1$ and bait construct of LtEPG1 were assayed for growth on SD/-Leu/-Trp/-His plates and for $\beta$-galactosidase activities. Yeast transformants expressing the empty prey construct $p G A D T 7$ with empty bait construct $p G B K T 7$ were used as the negative control. Yeast cells expressing the $p G A D T 7-T$ prey construct with the $p G B K T 7-53$ bait construct were used as the positive control. Plates were photographed 3 days after inoculation. B, Protein GST-LtEPG1 interacts with MBP-KIN $\beta 1$ using MBP pull-down assays. The recombinant proteins GST-LtEPG1 and MBPKIN $\beta 1$ expressed in E. coli were subjected to MBP pull-down analyses. The interacting proteins were detected via immunoblotting analyses.
Many glycoside hydrolase family proteins, including XEG1 of Phytophthora sojae (Ma et al. 2015), chitinases and xylanases of many fungal taxa (Ron and Avni 2004; Xu et al. 2016), INF1 of $P$. capsica and P. infestans (Kamoun et al. 1998; Liu et al. 2015), Avr2, Avr4, Avr4E, Avr5, and Avr9 of Cladosporium fulvum (de Wit 2016), and fungal endopolygalacturonases (Zhang et al. 2014), have been confirmed to be able to trigger plant defensive responses (Misas-Villamil and van der Hoorn 2008). In this study, LtEPG1 was also confirmed to induce the cell death, which suggest that LtEPG1 may function as a microbe-associated molecular pattern (MAMP) during the invasion process of $L$. theobromae.

Furthermore, one protein, KIN $\beta 1$, was confirmed to interact with LtEPG1 by yeast two-hybridization. KIN $\beta 1$ was reported to be a regulatory subunit of the probable trimeric SNF1-related protein kinase (SnRK) complex, which has been previously identified to have a key role in the signal transduction cascade regulating gene expression and carbohydrate metabolism in higher plants (Emanuelle et al. 2015). Gene expression analysis showed that $K I N \beta 1$ was considerably down-regulated during infectious stages, which was completely the opposite of the expression pattern of LtEPG1, suggesting that $K I N \beta 1$ may be negatively regulated during the infection. Based on the results mentioned above, we inferred that LtEPG1 may be able to manipulate the expression of resistancerelated genes and the host immune response by interfering with the KIN $\beta 1$-mediated signaling pathway. Substitution of eight conserved residues resulted in almost entire loss of the polygalacturonase activity, whereas their ability to trigger cell death in $N$. benthamiana was not affected, indicating the function of LtEPG1 as a MAMP was independent of its enzymatic activity. The enzymatic activity of LtEPG1 is related to these key amino acids, and this explains the loss of activity in the mutated forms of the enzyme. As suggested by the above results, the elicitor activity of LtEPG1 may relate to its interaction with KIN $\beta 1$. Since the point mutated forms of LtEPG1 still function as elicitors, they may still be able to interact with KIN $\beta 1$.

LtEPG1 was found to be a virulence factor in L. theobromae. Furthermore, the polygalacturonase activity of LtEPG1 was independent of its elicitor activity. Interestingly, it was found that LtEPG1 interacted with KIN $\beta 1$ in $V$. vinifera. Given the important roles LtEPG1 played during the infection process, further studies are warranted on LtEPG1 and KIN $\beta 1$, specifically on the regulatory pathways.

\section{ACKNOWLEDGMENTS}

We thank Wenxian Sun and Zejian Guo at China Agricultural University for providing vectors and yeast strain required for the study. K. D. Hyde thanks Kunming Institute of Botany, Chinese Academy of Sciences (project 2013T2S0030), for the Visiting Professorship for Senior International Scientists.

\section{LITERATURE CITED}

Becker, D. M., and Lundblad, V. 1994. Introduction of DNA into yeast cells. Curr. Protoc. Mol. Biol. 27:13-17.

Chethana, K. W. T., Li, X., Zhang, W., Hyde, K. D., and Yan, J. 2016. Trail of decryption of molecular research on Botryosphaeriaceae in woody plants. Phytopathol. Mediterr. 55:147-171.

Cheung, M.-Y., Zeng, N.-Y., Tong, S.-W., Li, W.-Y. F., Xue, Y., Zhao, K.-J., Wang, C., Zhang, Q., Fu, Y., Sun, Z., and Sun, S. S. M. 2008. Constitutive expression of a rice GTPase-activating protein induces defense responses. New Phytol. 179:530-545.

Cosgrove, D. J. 2005. Growth of the plant cell wall. Nat. Rev. Mol. Cell Biol. 6:850-861

D’Ovidio, R., Mattei, B., Roberti, S., and Bellincampi, D. 2004. Polygalacturonases, polygalacturonase-inhibiting proteins and pectic oligomers in plant-pathogen interactions. Biochim. Biophys. Acta. Proteins Proteomics 1696:237-244.

de Wit, P. J. G. M. 2016. Cladosporium fulvum effectors: Weapons in the arms race with tomato. Annu. Rev. Phytopathol. 54:1-23.

Di Pietro, A., and Roncero, M. I. G. 1998. Cloning, expression, and role in pathogenicity of pg1 encoding the major extracellular endopolygalacturonase 
of the vascular wilt pathogen Fusarium oxysporum. Mol. Plant-Microbe Interact. 11:91-98.

Drew, D. E., von Heijne, G., Nordlund, P., and de Gier, J.-W. L. 2001. Green fluorescent protein as an indicator to monitor membrane protein overexpression in Escherichia coli. FEBS Lett. 507:220-224.

Durrands, P. K., Keene, R. A., Cooper, R. M., O'garro, L. W., and Clarkson, J. M. 1988. Polygalacturonase isozyme profiles of Verticillium dahliae isolates races 1 and 2 from different geographical origins. Trans. Br. Mycol. Soc. 91:533-536.

Emanuelle, S., Hossain, M. I., Moller, I. E., Pedersen, H. L., van de Meene, A. M. L., Doblin, M. S., Koay, A., Oakhill, J. S., Scott, J. W., Willats, W. G., and Kemp, B. E. 2015. SnRK1 from Arabidopsis thaliana is an atypical AMPK. Plant J. 82:183-192.

Fabro, G., Steinbrenner, J., Coates, M., Ishaque, N., Baxter, L., Studholme, D. J., Körner, E., Allen, R. L., Piquerez, S. J., Rougon-Cardoso, A., and Greenshields, D. 2011. Multiple candidate effectors from the oomycete pathogen Hyaloperonospora arabidopsidis suppress host plant immunity. PLoS Pathog 7:e1002348.

Gao, S., Choi, G. H., Shain, L., and Nuss, D. L. 1996. Cloning and targeted disruption of enpg-1, encoding the major in vitro extracellular endopolygalacturonase of the chestnut blight fungus, Cryphonectria parasitica. Appl. Environ. Microbiol. 62:1984-1990.

Gibson, D. M., King, B. C., Hayes, M. L., and Bergstrom, G. C. 2011. Plant pathogens as a source of diverse enzymes for lignocellulose digestion. Curr. Opin. Microbiol. 14:264-270.

Gu, B., Kale, S. D., Wang, Q., Wang, D., Pan, Q., Cao, H., Meng, Y., Kang, Z., Tyler, B. M., and Shan, W. 2011. Rust secreted protein Ps87 is conserved in diverse fungal pathogens and contains a RXLR-like motif sufficient for translocation into plant cells. PLoS One 6:e27217.

Hall, T. A. 1999. BIOEDIT: A user-friendly biological sequence alignment editor and analysis program for Windows 95/98/NT. Nucleic Acids Symp. Ser. 41:95-98.

Hématy, K., Cherk, C., and Somerville, S. 2009. Host-pathogen warfare at the plant cell wall. Curr. Opin. Plant Biol. 12:406-413.

Henrissat, B. 1991. A classification of glycosyl hydrolases based on amino acid sequence similarities. Biochem. J. 280:309-316.

Herron, S. R., Benen, J. A. E., Scavetta, R. D., Visser, J., and Jurnak, F. 2000. Structure and function of pectic enzymes: Virulence factors of plant pathogens. Proc. Natl. Acad. Sci. 97:8762-8769.

Hillis, D. M., and Bull, J. J. 1993. An empirical test of bootstrapping as a method for assessing confidence in phylogenetic analysis. Syst. Biol. 42: 182-192.

Horton, R. M. 1995. PCR-mediated recombination and mutagenesis. Mol. Biotechnol. 3:93-99.

Howell, C. R. 1976. Use of enzyme-deficient mutants of Verticillium dahliae to assess the importance of pectolytic enzymes in symptom expression of Verticillium wilt of cotton. Physiol. Plant Pathol. 9:279-283.

Isshiki, A., Akimitsu, K., Yamamoto, M., and Yamamoto, H. 2001. Endopolygalacturonase is essential for citrus black rot caused by Alternaria citri but not brown spot caused by Alternaria alternata. Mol. Plant-Microbe Interact. 14:749-757.

Jacobs, K. A., Collins-Racie, L. A., Colbert, M., Duckett, M., Golden-Fleet, M., Kelleher, K., Kriz, R., LaVallie, E. R., Merberg, D., Spaulding, V., and Stover, J. 1997. A genetic selection for isolating cDNAs encoding secreted proteins. Gene 198:289-296.

Kamoun, S., van West, P., Vleeshouwers, V. G. A. A., de Groot, K. E., and Govers, F. 1998. Resistance of Nicotiana benthamiana to Phytophthora infestans is mediated by the recognition of the elicitor protein INF1. Plant Cell 10:1413-1425.

Kars, I., Krooshof, G. H., Wagemakers, L., Joosten, R., Benen, J. A. E., and van Kan, J. A. L. 2005. Necrotizing activity of five Botrytis cinerea endopolygalacturonases produced in Pichia pastoris. Plant J. 43:213-225.

Katoh, K., and Toh, H. 2008. Recent developments in the MAFFT multiple sequence alignment program. Brief. Bioinform. 9:286-298.

Kjøller, A., and Struwe, S. 2002. Fungal communities, succession, enzymes, and decomposition. Pages 267-284 in: Enzymes in the Environment: Activity, Ecology and Applications. R. G. Burns and R. P. Dick, eds. CRC Press, Boca Raton, FL.

Kubicek, C. P., Starr, T. L., and Glass, N. L. 2014. Plant cell wall-degrading enzymes and their secretion in plant-pathogenic fungi. Annu. Rev. Phytopathol. 52:427-451.

Li, R., Rimmer, R., Buchwaldt, L., Sharpe, A. G., Séguin-Swartz, G., and Hegedus, D. D. 2004. Interaction of Sclerotinia sclerotiorum with Brassica napus: Cloning and characterization of endo- and exo-polygalacturonases expressed during saprophytic and parasitic modes. Fungal Genet. Biol. 41: 754-765.

Liu, J., Elmore, J. M., Lin, Z.-J. D., and Coaker, G. 2011. A receptor-like cytoplasmic kinase phosphorylates the host target RIN4, leading to the activation of a plant innate immune receptor. Cell Host Microbe 9:137-146.
Liu, Z., Qiu, A., Shi, L., Cai, J., Huang, X., Yang, S., Wang, B., Shen, L., Huang, M. K., Mou, S. L., and Ma, X. L. 2015. SRC2-1 is required in PcINF1-induced pepper immunity by acting as an interacting partner of PcINF1. J. Exp. Bot. 66:3683-3698.

Ma, Z., Song, T., Zhu, L., Ye, W., Wang, Y., Shao, Y., Dong, S., Zhang, Z., Dou, D., Zheng, X., and Tyler, B. M. 2015. A Phytophthora sojae glycoside hydrolase 12 protein is a major virulence factor during soybean infection and is recognized as a PAMP. Plant Cell 27:2057-2072.

Mann, B. 1962. Role of pectic enzymes in the Fusarium wilt syndrome of tomato. Trans. Br. Mycol. Soc. 45:169-178.

Mellerowicz, E. J., Baucher, M., Sundberg, B., and Boerjan, W. 2001. Unravelling cell wall formation in the woody dicot stem. Plant Mol. Biol. 47:239-274.

Miller, G. L. 1959. Use of dinitrosalicylic acid reagent for determination of reducing sugar. Anal. Chem. 31:426-428.

Misas-Villamil, J. C., and van der Hoorn, R. A. L. 2008. Enzyme-inhibitor interactions at the plant-pathogen interface. Curr. Opin. Plant Biol. 11: 380-388.

Mohnen, D. 2008. Pectin structure and biosynthesis. Curr. Opin. Plant Biol. 11:266-277.

Oeser, B., Heidrich, P. M., Müller, U., Tudzynski, P., and Tenberge, K. B. 2002. Polygalacturonase is a pathogenicity factor in the Claviceps purpurea/rye interaction. Fungal Genet. Biol. 36:176-186.

Page, R. D. M. 1996. Tree View: An application to display phylogenetic trees on personal computers. Bioinformatics 12:357-358.

Petersen, T. N., Brunak, S., von Heijne, G., and Nielsen, H. 2011. SignalP 4.0: Discriminating signal peptides from transmembrane regions. Nat. Methods 8:785-786.

Pham, T. A., Kawai, S., and Murata, K. 2011. Visualization of the synergistic effect of lithium acetate and single-stranded carrier DNA on Saccharomyces cerevisiae transformation. Curr. Genet. 57:233-239.

Poinssot, B., Vandelle, E., Bentéjac, M., Adrian, M., Levis, C., Brygoo, Y., Garin, J., Sicilia, F., Coutos-Thévenot, P., and Pugin, A. 2003. The endopolygalacturonase 1 from Botrytis cinerea activates grapevine defense reactions unrelated to its enzymatic activity. Mol. Plant-Microbe Interact. 16: 553-564.

Reignault, P., Valette-Collet, O., and Boccara, M. 2007. The importance of fungal pectinolytic enzymes in plant invasion, host adaptability and symptom type. Eur. J. Plant Pathol. 120:1-11.

Ron, M., and Avni, A. 2004. The receptor for the fungal elicitor ethyleneinducing xylanase is a member of a resistance-like gene family in tomato. Plant Cell 16:1604-1615.

Sakamoto, M., Tomita, R., and Kobayashi, K. 2009. A protein containing an $\mathrm{XYPPX}$ repeat and a $\mathrm{C} 2$ domain is associated with virally induced hypersensitive cell death in plants. FEBS Lett. 583:2552-2556.

Scott-Craig, J. S., Panaccione, D. G., Cervone, F., and Walton, J. D. 1990. Endopolygalacturonase is not required for pathogenicity of Cochliobolus carbonum on maize. Plant Cell 2:1191-1200.

Sharma, S., Sharma, S., Hirabuchi, A., Yoshida, K., Fujisaki, K., Ito, A., Uemura, A., Terauchi, R., Kamoun, S., Sohn, K. H., and Jones, J. D. 2013. Deployment of the Burkholderia glumae type III secretion system as an efficient tool for translocating pathogen effectors to monocot cells. Plant J. 74:701-712.

Shieh, M. T., Brown, R. L., Whitehead, M. P., Cary, J. W., Cotty, P. J., Cleveland, T. E., and Dean, R. A. 1997. Molecular genetic evidence for the involvement of a specific polygalacturonase, $\mathrm{P} 2 \mathrm{c}$, in the invasion and spread of Aspergillus flavus in cotton bolls. Appl. Environ. Microbiol. 63: 3548-3552.

Slippers, B., and Wingfield, M. J. 2007. Botryosphaeriaceae as endophytes and latent pathogens of woody plants: Diversity, ecology and impact. Fungal Biol. Rev. 21:90-106.

Sugantha Priya, S., Gowri Shankar, J., Thirumalaisamy, R., Kavitha, P., Prakash, B., Arunachalam, G., and Selvamuthukumar, S. 2010. Over expression of IPTG inducible GST protein in E. coli BL21. J. Biomed. Sci. Res. 2:54-59.

Swofford, D. L. 2002. PAUP* 4.0: Phylogenetic analysis using parsimony (* and other methods). Sinauer Associates, Sunderland, MA.

Tabata, S., Kaneko, T., Nakamura, Y., Kotani, H., Kato, T., Asamizu, E., Miyajima, N., Sasamoto, S., Kimura, T., Hosouchi, T., Kawashima, K., Kohara, M., Matsumoto, M., Matsuno, A., Muraki, A., Nakayama, S., Nakazaki, N., Naruo, K., Okumura, S., Shinpo, S., Takeuchi, C., Wada, T., Watanabe, A., Yamada, M., Yasuda, M., Sato, S., de la Bastide, M., Huang, E., Spiegel, L., Gnoj, L., O’Shaughnessy, A., Preston, R., Habermann, K., Murray, J., Johnson, D., Rohlfing, T., Nelson, J., Stoneking, T., Pepin, K., Spieth, J., Sekhon, M., Armstrong, J., Becker, M., Belter, E., Cordum, H., Cordes, M., Courtney, L., Courtney, W., Dante, M., Du, H., Edwards, J., Fryman, J., Haakensen, B., Lamar, E., Latreille, P., Leonard, S., Meyer, R., Mulvaney, E., Ozersky, P., Riley, A., Strowmatt, C., Wagner-McPherson, C., Wollam, A., Yoakum, M., Bell, M., Dedhia, N., Parnell, L., Shah, R., 
Rodriguez, M., See, L. H., Vil, D., Baker, J., Kirchoff, K., Toth, K., King, L., Bahret, A., Miller, B., Marra, M., Martienssen, R., McCombie, W. R., Wilson, R. K., Murphy, G., Bancroft, I., Volckaert, G., Wambutt, R., Düsterhöft, A., Stiekema, W., Pohl, T., Entian, K. D., Terryn, N., Hartley, N., Bent, E., Johnson, S., Langham, S. A., McCullagh, B., Robben, J., Grymonprez, B., Zimmermann, W., Ramsperger, U., Wedler, H., Balke, K., Wedler, E., Peters, S., van Staveren, M., Dirkse, W., Mooijman, P., Lankhorst, R. K., Weitzenegger, T., Bothe, G., Rose, M., Hauf, J., Berneiser, S., Hempel, S., Feldpausch, M., Lamberth, S., Villarroel, R., Gielen, J., Ardiles, W., Bents, O., Lemcke, K., Kolesov, G., Mayer, K., Rudd, S., Schoof, H., Schueller, C., Zaccaria, P., Mewes, H. W., Bevan, M., and Fransz, P. 2000. Sequence and analysis of chromosome 5 of the plant Arabidopsis thaliana. Nature 408:823-826.

ten Have, A., Mulder, W., Visser, J., and van Kan, J. A. L. 1998. The endopolygalacturonase gene Bcpg1 is required to full virulence of Botrytis cinerea. Mol. Plant-Microbe Interact. 11:1009-1016.

Treco, D. A., and Lundblad, V. 1993. Preparation of yeast media. Curr. Protoc. Mol. Biol. 23:13.1.1-13.1.7.

van der Vlugt-Bergmans, C. J. B., Meeuwsen, P. J. A., Voragen, A. G. J., and van Ooyen, A. J. J. 2000. Endo-xylogalacturonan hydrolase, a novel pectinolytic enzyme. Appl. Environ. Microbiol. 66:36-41.

van Santen, Y., Benen, J. A. E., Schröter, K. H., Kalk, K. H., Armand, S., Visser, J., Uemura, A., Terauchi, R., Kamoun, S., Sohn, K. H., and Jones, J. D. 1999. 1.68- $\AA$ crystal structure of endopolygalacturonase II from
Aspergillus niger and identification of active site residues by site-directed mutagenesis. J. Biol. Chem. 274:30474-30480.

Voragen, A. G. J., Coenen, G. J., Verhoef, R. P., and Schols, H. A. 2009. Pectin, a versatile polysaccharide present in plant cell walls. Struct. Chem. 20:263-275.

Wilcox, W. F., Gubler, W. D., and Uyemoto, J. K. 2015. Compendium of Grape Diseases, Disorders, and Pests, 2nd ed. W. F. Wilcox, W. D. Gubler, and J. K. Uyemoto, eds. American Phytopathological Society, St. Paul, MN.

Xu, J., Xu, X., Tian, L., Wang, G., Zhang, X., Wang, X., and Guo, W. 2016. Discovery and identification of candidate genes from the chitinase gene family for Verticillium dahliae resistance in cotton. Sci. Rep. 6:29022.

Yan, J. Y., Zhao, W. S., Chen, Z., Xing, Q. K., Zhang, W., Chethana, K. W. T., Xue, M. F., Xu, J. P., Phillips, A. J., Wang, Y., and Liu, J. H. 2018. Comparative genome and transcriptome analyses reveal adaptations to opportunistic infections in woody plant degrading pathogens of Botryosphaeriaceae. DNA Res. 25:87-102.

Yang, H., Yang, S., Li, Y., and Hua, J. 2007. The Arabidopsis BAP1 and BAP2 genes are general inhibitors of programmed cell death. Plant Physiol. 145: $135-146$.

Zhang, L., Kars, I., Essenstam, B., Liebrand, T. W. H., Wagemakers, L., Elberse, J., Tagkalaki, P., Tjoitang, D., van den Ackerveken, G., and van Kan, J. A. 2014. Fungal endopolygalacturonases are recognized as microbe-associated molecular patterns by the Arabidopsis receptor-like protein responsiveness to Botrytis polygalacturonases. Plant Physiol. 164:352-364. 